\title{
PERBAIKAN LINGKAR PERUT, TEKANAN DARAH, DAN BODY MASS INDEX WANITA SINDROM METABOLIK MENGGUNAKAN YOGURT SUSU KECAMBAH KACANG MERAH
}

\author{
Amelioration Abdominal Circumference, Blood Pressure, and Body Mass Index \\ Women with Metabolic Syndrome Using Red Kidney Bean Sprout Milk Yogurt
}

\author{
Hery Winarsi ${ }^{1)}$, Aisyah Tri Septiana ${ }^{2)}$, Avia Roselia ${ }^{3)}$ \\ ${ }^{1}$ Program Studi Ilmu Gizi, Fakultas Ilmu-ilmu Kesehatan, Universitas Jenderal Soedirman; \\ ${ }^{2}$ Jurusan Teknologi Pertanian, Fakultas Pertanian, Universitas Jenderal Soedirman. \\ ${ }^{3}$ Rumah Sakit Umum Sinar Kasih. Purwokerto. \\ *)Alamat korespondensi: winarsi12@gmail.com
}

\begin{abstract}
This study aims to determine the effect of red kidney bean sprout milk yogurt (Rides-Yo) on abdominal circumference, blood pressure, and body mass index of metabolic syndrome women. Red kidney bean sprouts milk added with $10 \%$ sucrose and $10 \%$ skim milk pasteurized at $70^{\circ} \mathrm{C}$ for 10 minutes, then cooled to $45^{\circ} \mathrm{C}$. Inoculated with lactic acid bacteria $2 \%$ of the total volume of red bean milk, incubated at $27-35^{\circ} \mathrm{C}$ for 24 hours. As many as 30 women, 40-65 years aged, central obesity, hypertension, and hyperlipidemia, live in the Baturraden subdistrict, Banyumas Regency, and are willing to sign informed consent. Subjects were randomly divided into 3 groups; the first group was given Rides-Yo; the second group was given a placebo; and group 3 took medicine from a doctor. A total of $200 \mathrm{~mL} /$ day of Rides-Yo or placebo was given to the subjects for 2 months. Before and after the intervention, subjects were measured for abdominal circumference, blood pressure, weight and height. There was a decrease in abdominal circumference $(P=0,018)$, systole and diastolic blood pressure $(P<0.038$ and $P=0,032)$, and BMI $(P=0,039)$ in the group receiving Rides-Yo, compared to placebo and control groups. Thus, Rides-Yo is able to improve the health status of women with metabolic syndrome.
\end{abstract}

Keyword: abdominal circumference, blood pressure, BMI, metabolic syndrome, red kidney bean sprouts milk yogurt

\begin{abstract}
ABSTRAK
Penelitian ini bertujuan untuk mengetahui efek yogurt susu kecambah kacang merah (Yosukamera) terhadap lingkar perut, tekanan darah, dan body mass index wanita sindrom metabolic. Susu kecambah kacang merah ditambah susu skim $10 \%$ dan sukrosa $10 \%$ dipasteurisasi pada suhu $70^{\circ} \mathrm{C}$ selama 10 menit, kemudian didinginkan sampai suhu $45^{\circ} \mathrm{C}$. Diinokulasi dengan starter bakteri asam laktat $2 \%$ volume total, diinkubasikan pada $27-35^{\circ} \mathrm{C}$ selama 24 jam. Subjek adalah 30 orang wanita, usia 40-65 tahun, obesitas sentral, hipertensi, hiperlipidemia tinggal di wilayah kecamatan Baturraden, Kabupaten Banyumas, dan bersedia menandatangani informed consent. Subjek dibagi secara acak menjadi 3 kelompok; kelompok pertama diberi Yosukamera; kelompok kedua diberi placebo; dan kelompok 3 hanya minum obat dari dokter. Sebanyak $200 \mathrm{~mL} /$ hari Yosukamera ataupun placebo diberikan kepada subjek selama 2 bulan. Sebelum dan setelah intervensi, subjek diukur lingkar perut, tekanan darah, berat, dan tinggi badannya. Terjadi penurunan lingkar perut $(\mathrm{P}<0.018)$, tekanan darah sistol dan diastole $(\mathrm{P}=0,038$ dan $\mathrm{P}=0,032)$, dan $\mathrm{BMI}$ $(\mathrm{P}=0,039)$ pada kelompok yang mendapatkan yosukamera, dibandingkan kelompok plasebo maupun kontrol. Dengan demikian, yosukamera mampu memperbaiki status kesehatan wanita penderita sindrom metabolic.
\end{abstract}

Kata Kunci: lingkar perut, tekanan darah, BMI, sindrom metabolic, yogurt susu kecambah kacang merah 


\section{PENDAHULUAN}

Prevalensi sindrom metabolik (SM)

di Asia meningkat cepat, didominasi negara berkembang, seperti Indonesia 28,4\% dan Malaysia 27,5\% (Soewondo et al., 2010; Rampal et al., 2012). Obesitas sentral, dislipidemia, hipertensi, resistensi insulin, intoleransi glukosa, disfungsi endotel, inflamasi, dan stres oksidatif merupakan komponen utama SM. Kriteria yang sering digunakan untuk menilai pasien SM adalah NCEP-ATP III, yaitu apabila memenuhi 3 dari 5 kriteria berikut, antara lain lingkar perut $>102 \mathrm{~cm}$ untuk pria dan $>88 \mathrm{~cm}$ untuk wanita; hipertrigliseridemia (>150 mg/dL), kadar HDL $<40 \mathrm{mg} / \mathrm{dL}$ untuk pria dan $<50$ $\mathrm{mg} / \mathrm{dL}$ untuk wanita; tekanan darah >130/85 mmHg; dan kadar glukosa darah puasa >110 $\mathrm{mg} / \mathrm{dL}$ (IDF, 2005).

Kriteria-kriteria tersebut saling berkaitan, semakin besar lingkar perut menggambarkan semakin tinggi kandungan lemak dalam tubuh. Karenanya, lingkar perut menjadi indikator obesitas abdominal yang terkait dengan kadar HDL (Eyben et al., 2003). Sandhu et al. (2008) menambahkan bahwa ukuran lingkar perut dapat menjadi prediktor kadar lipid darah. Lingkar perut yang tinggi menurunkan kadar HDL, meningkatkan tekanan darah, dan bila tidak dikendalikan dapat berkembang menjadi penyakit jantung koroner, stroke, dan gagal ginjal (Lu et al., 2014). Obesitas sentral juga berdampak obesitas secara umum, BMI meningkat dan berakibat terganggunya kerja sistem imun dan rendahnya status antioksidan (Marti et al., 2001). Oleh sebab itu lingkar perut, tekanan darah, dan BMI harus dikendalikan.

Beberapa peneliti melaporkan bahwa produk pangan kaya antioksidan dapat memperbaiki status antioksidan (Winarsi et al., 2016), berat badan (Winarsi, 2013), profil lipid (Ismail et al., 2015), dan tekanan darah (Rangel-Huerta et al., 2015). Winarsi et al. (2019) menemukan produk probiotik Yogurt susu kecambah kacang merah (Yosukamera) yang disukai dan kaya antioksidan fenolik $639 \mathrm{mg} \mathrm{GAE} / \mathrm{L}$, serat pangan 6,29\%, dan protein terlarut $38 \%$. Kumalaningsih et al. (2016) menambahkan, yogurt kacangkacangan memiliki kadar serat dan protein tinggi, bebas laktosa, dan kasein.

Dalam starter Bakteri Asam Laktat (BAL), Streptococcus thermophillus dan Lactobacillus bulgaricus menghasilkan konsistensi yogurt menyerupai pudding, sedangkan Lactobacillus acidophilus meningkatkan produksi asam laktat, sehingga yogurt berasa asam, penampakannya baik sekali, harum, kental dan homogen (Sunarlim dan Usmiati, 2010), serta memiliki aroma 
spesifik yang berasal dari senyawa karbonil seperti diasetil dan asetaldehid (Cheng, 2010). Nilai gizi yogurt lebih tinggi daripada bahan segarnya, demikian pula lemaknya juga lebih rendah (Martínez-González et al., 2014), sehingga bermanfaat mengatasi masalah pencernaan (Fernandez dan Marette, 2017), penyembuhan luka lambung (Rodríguez et al., 2009), menurunkan kolesterol darah, resiko penyakit jantung, dan hipertensi (Cavallini et al., 2011; Buendia et al., 2018), serta mencegah osteoporosis (Rizzoli, 2014).

Beberapa peneliti melaporkan bahwa produk kaya antioksidan fenolik terbukti melindungi tubuh dari stress oksidatif dan bersifat imunomodulator (Oomah et al., 2010), serta mengendalikan berat badan (Winarsi et al., 2013). Permasalahannya, apakah Yosukamera dapat memperbaiki lingkar perut, tekanan darah, dan body mass index wanita penderita SM? Penelitian ini bertujuan untuk mengetahui efek Yosukamera terhadap lingkar perut, tekanan darah, dan body mass index wanita penderita SM.

\section{METODE}

Penelitian true experiment ini diawali dengan produksi Yosukamera menurut
Winarsi et al. (2019), dilanjutkan dengan intervensi produk kepada subjek.

\section{a. Produksi Yosukamera}

Kacang merah segar disortasi kemudian di cuci dengan alir mengalir. Selanjutnya kacang merah direndam selama 12 jam kemudian diletakan diwadah plastik yang telah diberi alas kapas yang sudah dibasahi dengan air dan ditempatkan ditempat yang gelap, hingga tumbuh kecambah dengan panjang 0,5-1 $\mathrm{cm}$. Dengan perbandingan 1:8 untuk kecambah dan air, diblender, dan disaring, sehingga diperoleh cairan susu kecambah kacang merah.

Susu kecambah kacang merah ditambahkan susu skim 10\% dan sukrosa $10 \%$, dipasteurisasi pada suhu $70^{\circ} \mathrm{C}$ selama 10 menit, kemudian didinginkan sampai suhu $45^{\circ} \mathrm{C}$. Diinokulasi starter BAL komersial (Lactobacilus bulgaricus, Streptococcus thermophillus, Lactobacillus acidophilus) sebanyak $2 \%$ dari volume total. Diinkubasikan pada suhu ruang selama 24 jam (Winarsi et al., 2019)

\section{b. Seleksi subjek penelitian}

Sejumlah 30 orang dengan kriteria inklusi wanita umur 40-65 tahun sindrom metabolic dengan obesitas sentral (lingkar perut > $80 \mathrm{~cm})$, dyslipidemia, hipertensi (>140/90 mmHg), BMI $>27 \mathrm{~kg} / \mathrm{m}^{2}$, tinggal di wilayah kecamatan Baturraden, Kabupaten 
Banyumas, dan bersedia menandatangani informed consent. Subjek dibagi 3 secara acak, masing-masing 10 orang. Semua kelompok minum obat dari dokter. Kelompok I, diberi Yosukamera; II, placebo, sebanyak $200 \mathrm{ml} /$ hari, dan III, hanya minum obat selama 2 bulan. Pengukuran LP, TD, dan BMI dilakukan sebelum dan setelah intervensi.

\section{c. Pengukuran Lingkar perut}

Pertama-tama subjek dijelaskan tujuan pengukuran lingkar perut dan tindakan yang akan dilakukan dalam pengukuran. Dengan cara yang santun subjek diminta untuk membuka atau mengangkat pakaian bagian atas dan raba tulang rusuk terakhir untuk menetapkan titik pengukuran. Tetapkan titik batas tepi tulang rusuk paling bawah. Tetapkan titik ujung lengkung tulang pangkal paha atau panggul. Tetapkan titik tengah diantara titik tulang rusuk terakhir titik ujung lengkung tulang pangkal paha atau panggul dan tandai titik tengah tersebut dengan alat tulis. Subjek diminta untuk berdiri tegak dan melakukan ekspirasi normal. Lakukan pengukuran lingkar perut dimulai atau diambil dari titik tengah kemudian secara sejajar horizontal melingkari pinggang dan perut kembali menuju titik tengah di awal pengukuran. Pengukuran dilakukan pada saat akhir ekspirasi dengan kedua tungkai dilebarkan 20 hingga $30 \mathrm{~cm}$, dan subjek diminta untuk tidak menahan perutnya saat pengukuran dilakukan. Apabila subjek mempunyai perut yang buncit ke bawah, pengukuran mengambil bagian yang paling buncit lalu berakhir pada titik tengah tersebut lagi. Pita pengukur tidak boleh terlipat dan ukur lingkar perut mendekati angka $0,1 \mathrm{~cm}$ (Arianti dan Husna, 2017)

\section{d. Pengukuran Tekanan Darah}

Sebelum melakukan pengukuran tekanan darah, subjek sebaiknya menghindari aktivitas fisik seperti olahraga, merokok dan makan minimal 30 menit, serta duduk beristirahat setidaknya 5 hingga 15 menit, dan sedang dalam keadaan tidak ingin berkemih. Pengukuran dilakukan dalam ruangan dan kondisi yang tenang serta dalam posisi duduk. Subjek duduk dengan posisi kaki tidak menyilang dan posisikan kedua telapak kaki datar menyentuh lantai. Letakkan lengan kanan subjek di atas meja.Posisikan lengan kanan pasien sedikit fleksi dan lengan atas setinggi jantung. Singkirkan lengan baju pada lengan bagian kanan subjke dan memintanya untuk tetap duduk tanpa banyak bergerak dan tidak berbicara pada saat pengukuran. Letakkan manset mengelilingi lengan pasien bagian atas dengan selang berada di bagian depan 
dan selipkan bagian penjepitnya, atau tutup dengan klip yang sudah tersedia. Biarkan lengan dalam posisi tidak tegang dengan telapak tangan terbuka ke atas. Pastikan tidak ada lekukan pada pipa manset. Hubungkan manometer dengan manset. Rasakan dengan tangan pemeriksa yang lain adanya denyutan pada pergelangan tangan pasien, tutup katup yang berada pada gelembung karet dan pompakan manset sampai pemeriksa tidak dapat lagi merasakan denyutan. Kempiskan manset dan rasakan adanya denyutan di lekukan lengan. Letakkan sisi stetoskop yang berfungsi untuk mendengar di telinga pemeriksa dan bagian ujung stetoskop pada arteri di lekukan lengan pasien. Tutup katup dan kembangkan manset sampai skala yang terbaca berada di atas tekanan sistolik saat palpasi sebelumnya. Longgarkan katup dan kempiskan manset secara perlahan-lahan. Terdengar tekanan sistolik yang berupa suara turbulensi dan catat pada tekanan berapa

\section{HASIL DAN PEMBAHASAN}

\section{a. Karakteristik Yosukamera}

Yosukamera yang diproduksi menurut Winarsi et al. (2019) berbentuk cairan kental berwarna putih agak krem, dengan sensori agak suka hingga suka, rasanya agak asam, manis, aroma khas yogurt, mengandung kadar fenolik $565 \mathrm{mg} \mathrm{GAE} / \mathrm{L}$, protein terlarut suara itu mulai terdengar. Semakin lama terdengar suara murmur yang merupakan suara tekanan diastolik. Catat pada tekanan berapa suara murmur tersebut terdengar hingga suara tidak tedengar lagi. Catat hasil pengukuran pada lembar catatan observasi pengukuran tekanan darah. Lepaskan manset dan kempiskan manset dengan tangan untuk mengeluarkan udara dalam manset. Pengukuran dilakukan dua kali untuk mengambil rata-ratanya. Jarak antara dua pengukuran sebaiknya minimal 2 menit oleh orang yang sama dengan melepaskan mancet pada lengan (Arianti dan Husna, 2017).

\section{c. Penentuan BMI}

Diukur berat badan $(\mathrm{kg})$. Ditentukan tinggi badan (meter).

BMI $=($ berat badan $) /(\text { tinggi badan })^{2}=\mathrm{kg} / \mathrm{m}^{2}$

\section{d. Analisis Data}

Data dianalisis menggunakan uji t, dilanjutkan dengan DMRT pada taraf 5\% bila terdapat signifikansi.

$33,65 \%$, serat pangan $1,36 \%$, dan TPT $15,2^{\circ}$ Brix.

\section{b. Pengaruh Yosukamera terhadap LP wanita SM}

Yosukamera menurunkan ukuran lingkar perut dari 97 menjadi $89 \mathrm{~cm}$ $(\mathrm{P}=0,018)$, dibandingkan subjek yang menerima placebo $(\mathrm{P}=0,35)$ ataupun control $(\mathrm{P}=0,112)$ (Gambar 1). Besarnya lingkar 
perut menggambarkan jumlah lemak dalam tubuh. Elbers (1999) menambahkan bahwa lingkar perut merupakan indikator obesitas abdominal yang berkaitan dengan adanya perubahan kadar HDL. Pengukuran lingkar perut juga dapat memprediksi kadar lipid serum yang lebih baik dibandingkan dengan BMI (Sandhu et al., 2008).

Seperti yang ditemukan Nishihira $e t a l$. (2009) bahwa lingkar perut berkurang secara signifikan, dari 93,5 $\pm 11,0 \mathrm{~cm}$ menjadi 90,7 $\pm 9,8 \mathrm{~cm}$, dengan asupan oligonol selama 10 minggu. Oligonol mempromosikan produksi adiponektin dalam lemak visceral tikus bersamaan dengan berkurangnya akumulasi triasilgliserol (Fujii et al., 2008). Mekanisme intraseluler, dilaporkan bahwa aktivitas transkripsi $\mathrm{NF}-\mathrm{Kb}$ dan kinase diatur oleh sinyal ekstraseluler (Furuyashiki et al., 2004). Dalam hal ini, oligonol meningkatkan konsumsi energi melalui interaksi langsung dengan PPAR- $\alpha$, yang menjadikan hilangnya lemak visceral, sehingga ukuran lingkar perut berkurang.

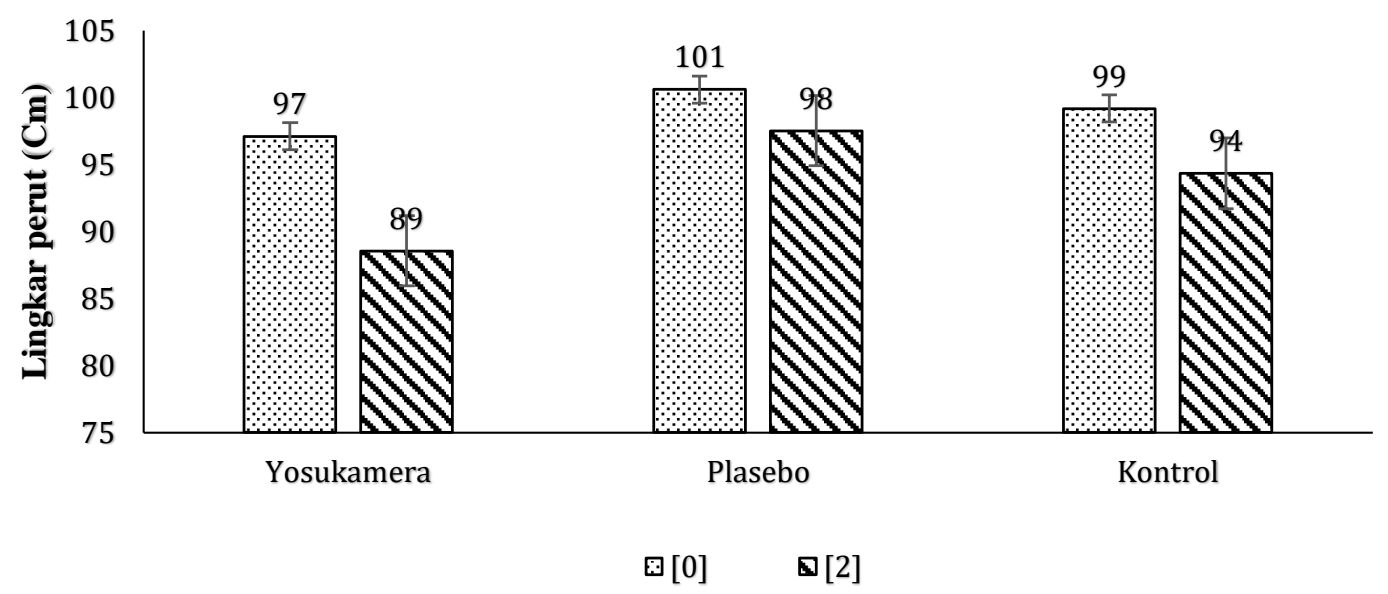

Gambar 1. Pengaruh Yosukamera terhadap lingkar perut wanita sindrom metabolik.

Oligonol adalah polifenol dari buah leci, yang dikonversikan menjadi senyawa dengan berat molekul kecil, sehingga mudah diserap oleh usus (Fujii et al., 2007). Oleh sebab itu, penurunan ukuran lingkar perut wanita SM mungkin terkait dengan kandungan antioksidan fenolik yosukamera. Winarsi et al. (2019) melaporkan bahwa yosukamera mengandung fenolik sebesar $565 \mathrm{mg}$ GAE/L. Fenolik yosukamera berperan mengikat lemak visceral untuk diekskresikan. Dalam sekali minum 
yosukamera, banyaknya fenolik yang diasup sebesar 113 mg/hari. Demikian, dengan mengkonsumsi selama 2 bulan dapat membersihkan lemak visceral, yang akhirnya ukuran lingkar perutnya menurun.

Obesitas sentral merupakan penanda risiko cardiovaskuler (Lee dan Pratley, 2007). Dengan ditemukannya penurunan lingkar perut tersebut, menjadi fakta bahwa yogurt susu kecambah kacang merah dapat dijadikan sebagai minuman fungsional pencegah risiko penyakit kardiovaskuler pada wanita sindrom metabolik.

Selain antioksidan fenolik, Yosukamera juga mengandung protein terlarut sebesar $33,65 \%$. Protein terlarut mudah dicerna dan diserap. Protein dapat memberikan efek termogenik pada tubuh sehingga menimbulkan rasa kenyang lebih lama dibandingkan dengan makro nutrien lainnya (Tome, 2004). Efek termogenik yang dihasilkan merupakan respon metabolik terhadap makanan. Dari asupan makanan tersebut menghasilkan peningkatan pengeluaran energi yang disebabkan oleh berbagai pemrosesan makanan (pencernaan, penyerapan, transportasi, metabolisme dan pembuangan nutrisi), sehingga terjadi peningkatan termal pada tubuh yang berupa pengeluaran energi (Pesta dan Samuel, 2014). Efek termogenik terjadi sebagai akibat tubuh tidak memiliki kapasitas penyimpanan protein, sehingga molekul tersebut segera dimetabolisme menjadi energi. Penurunan berat badan yang diketahui sebagai dampak efek termogenik protein, dilaporkan lebih tinggi (sebesar 20-35\%) dibandingkan dengan karbohidrat dan lemak (Thomas dan Frank, 2004; Westerterp et al, 1999). Terkait dengan rasa kenyang lebih panjang, maka frekuensi makan menjadi lebih jarang, sehingga menurunkan energi dan lemak perut, dan pada akhirnya menurunkan ukuran lingkar perut.

Serat pangan juga terkandung dalam Yosukamera (Winarsi et al., 2019). Serat pangan, dikenal juga sebagai serat diet atau dietary fiber, merupakan bagian dari tumbuhan yang dapat dikonsumsi dan tersusun dari karbohidrat yang memiliki sifat resisten terhadap proses pencernaan dan penyerapan di usus halus manusia, serta mengalami fermentasi sebagian atau keseluruhan di usus besar. Serat pangan adalah bagian dari bahan pangan yang tidak dapat dihirolisis oleh enzim. Serat pangan larut air (soluble fiber), seperti pektin dan beberapa hemiselulosa, memiliki kemampuan menyerap air dan dapat membentuk cairan kental dalam saluran pencernaan. Oleh karenanya, makanan kaya serat, waktu dicerna dalam lambung lebih 
lama, kemudian menarik air dan memberi rasa kenyang lebih lama, sehingga mencegah untuk mengkonsumsi makanan lebih banyak. Peningkatan konsumsi serat pangan telah direkomendasikan sebagai upaya yang aman dan praktis untuk mengurangi berat badan $(\mathrm{Li}$ dan Komarek, 2017). Yang et al. (2017) menunjukkan bahwa serat pangan membantu mengurangi glukosa darah, insulin dan konsentrasi trigliserida, serta menurunkan kadar kolesterol darah. Lebih dari itu, serat pangan dapat terfermentasi di dalam usus menghasilkan asam lemak rantai pendek (SCFA), diantaranya propionat yang dapat mencegah peningkatan kolesterol; dan asam butirat yang dapat mencegah kanker usus. Makanan dengan kandungan serat yang tinggi biasanya mengandung kalori, gula, dan lemak rendah, sehingga dapat membantu mengurangi resiko perkembangan obesitas.

\section{c. Pengaruh Yosukamera terhadap tekanan darah sistol dan diastole wanita sindrom metabolik}

Salah satu kriteria SM adalah hipertensi (IDF, 2005). Dalam penelitian ini subjek memiliki tekanan darah sistol 142-149 $\mathrm{mmHg}$, dan diastolnya 102-106 $\mathrm{mmHg}$. Namun demikian, setelah konsumsi yosukamera tekanan darah sistolnya menurun dari 142,8 menjadi $122 \mathrm{mmHg}$ $(\mathrm{P}=0,038) \quad$ (Gambar 2); diastolnya juga menurun dari 102,2 menjadi $84 \mathrm{mmHg}$ $(\mathrm{P}=0,032)$ (Gambar 3), dibandingkan dengan kelompok yang mendapat plasebo maupun kontrol. Sejalan dengan penelitian Hariri et al (2015), bahwa pemberian susu kedelai probiotik dapat menurunkan tekanan darah sistolik dan diastolik pada pasien diabetes tipe II. Khalesi et al. (2014) juga melaporkan pemberian yogurt susu kedelai (soyghurt) dapat menurunkan tekanan darah sistolik dan diastolik penderita hipertensi di Puskesmas Pasirkaliki Kota Cimahi. Dengan demikian penurunan tekanan darah dalam penelitian kemungkinan peran antioksidan fenolik dalam yosukamera.

Yogurt kecambah kacang merah mengandung fenolik dan asam amino semi esensial arginin yang tinggi (Winarsi et al., 2019; Nuryanti et al., 2014). Asam amino arginin merupakan prekusor nitric oxide (NO) yang memiliki efek vasodilator. Nitric oxide memiliki sifat menghambat agregasi (penggumpulan) platelet darah, sehingga dapat melancarkan sirkulasi darah (Ansarullah, et al., 2017), dan mengatur tekanan darah lebih baik. 


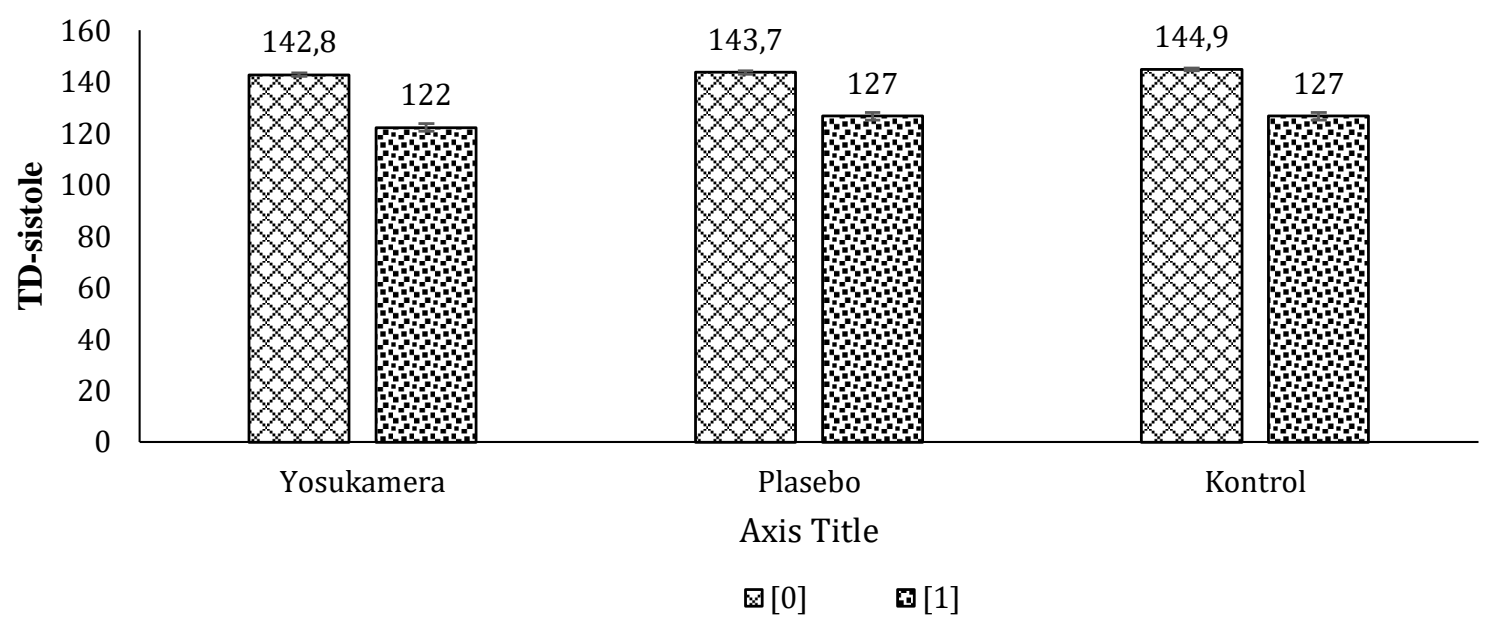

Gambar 2. Pengaruh Yosukamera terhadap tekanan darah sistole wanita sindrom metabolik.

Nitric Oxide membantu transport oksigen dengan melebarkan dinding pembuluh darah, dan mempermudah perpindahan gas dari darah ke jaringan, dan sebaliknya. NO disintesis oleh nitric oxide synthase (NOS) dari L-arginin. Setelah disintesis, NO mengalami difusi dari sel endotel ke sel otot polos pembuluh darah dan menyebabkan peningkatan cyclic guanosine monophosphate (cGMP) intraseluler. Peningkatan cGMP memacu terjadinya relaksasi otot polos pembuluh darah (Danuyanti et al., 2014). Menurut Vasdev dan Gill (2008), pemberian arginin sebesar 6 g/hari bersama dengan Angiotensin I Converting Enzyme (ACE) inhibitor dan diuretik selama 3 bulan dapat menurunkan tekanan darah sistolik dan diastolik.

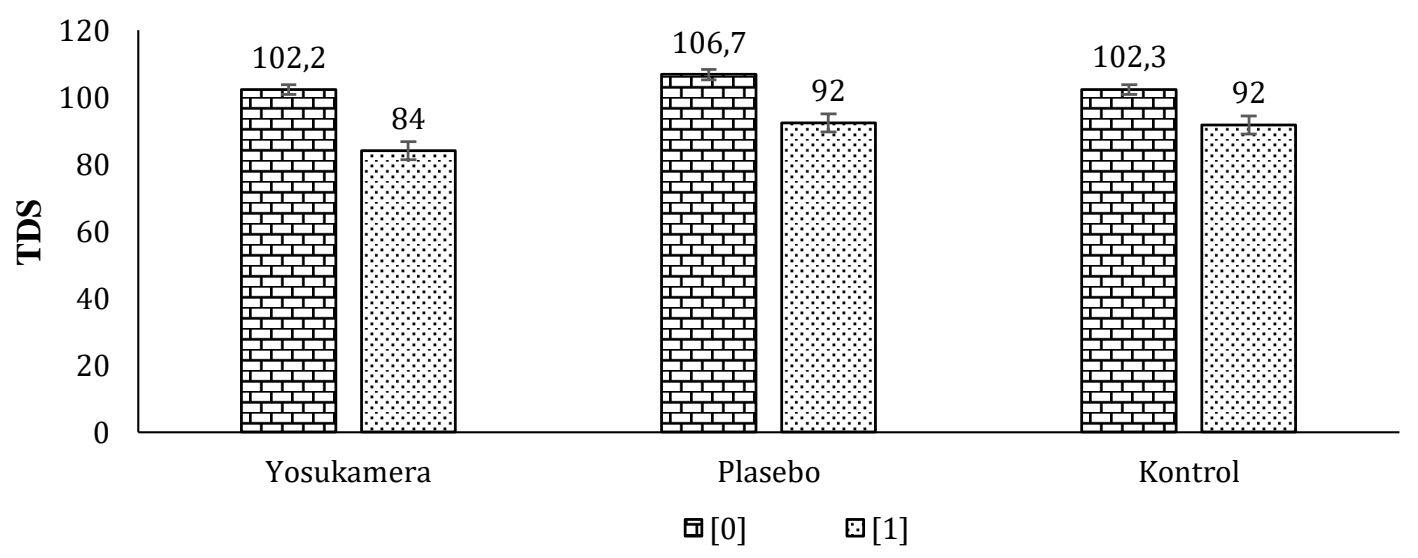

Gambar 3. Pengaruh Yosukamera terhadap tekanan darah Diastole wanita sindrom metabolik. 
Kandungan probiotik dalam produk fermentasi sangat penting karena memberikan kadar keasaman yang sesuai melalui produksi asam laktat. Apostolidis $e t$ al (2007) melaporkan bahwa asam laktat pada yogurt dengan kisaran 0,5-1\% secara positif mempengaruhi penghambatan ACE. Donkor et al (2005) menambahkan bahwa bakteri probiotik dalam susu kedelai dengan level minimal $6 \log \mathrm{CFU} / \mathrm{mL}$ memberikan efek terapi terhadap penghambatan ACE.

Bakteri asam laktat (BAL) yang terkandung dalam yogurt susu kecambah kacang merah juga berperan dalam penurunan tekanan darah. BAL melepaskan peptida bioaktif yang berperan sebagai $A C E$ inhibitor dalam sistem Renin-Angiotensin. Mekanisme kerja ACE-inhibitor yaitu menurunkan tekanan darah dengan cara menghambat dekapeptida Angiotensin I. Terhambatnya dekapeptida Angiotensin I tersebut, maka produksi Angiotensin II juga menurun, terjadi vasodilatasi otot halus disekitar pembuluh darah, sehingga mengendalikan tekanan darah (Elkhtab et al., 2017).

Beberapa peneliti menyebutkan bahwa fenolik menjadikan homeostasis tekanan darah dengan cara memperbaiki fungsi vascular, seperti yang diperankan polifenol Dark Chocolate (DC) (Grassi et al., 2005; Taubert et al., 2007; Faridi et al., 2008). Penelitian lain juga menyatakan bahwa polifenol DC berpengaruh pada metabolisme kortisol, sehingga mengendalikan tekanan darah pada obesitas. Kortisol adalah hormon yang memainkan peran penting dalam homeostasis kadar glukosa dan tekanan darah.

Selain itu, dalam usus besar fenolik memungkinkan mengalami deglikosilasi oleh mikroflora usus, menghasilkan aglikon aktif (Roowi et al., 2009). Kedua bentuk glikosida tersebut memiliki sifat antiinflamasi, hipolipidemik, dan vasoprotektif yang dapat menyebabkan efek perbaikan tekanan darah dan mengontrol LDL (Pérez-Jiménez et al., 2010). Yamamoto et al. (2008) menambahkan bahwa flavanon (salah satu jenis fenolik) berpotensi hipotensi berkaitan dengan mekanismenya vasodilatasi yang dimediasi oleh NO.

Menurut Kartini et al. (2018), yogurt susu kecambah kacang merah (yosukamera) mengandung kalium sebesar $3051,1 \mathrm{mg} / \mathrm{L}$, sehingga dengan takaran saji $200 \mathrm{~mL}$ didapatkan asupan kalium sebesar 610,22 mg. Kadar kalium yang tinggi ini dapat dijadikan sebagai terapi penderita hipertensi. 
Asupan natrium berpengaruh terhadap pembuluh darah yaitu dengan menurunkan resistensi pembuluh darah perifer sehingga menyebabkan pelebaran arteri, peningkatan ekskresi air dan natrium dari tubuh, penekanan sekresi renin angiotensin, dan stimulasi aktivitas pompa natrium-kalium. Kalium memiliki efek natriuretik dengan mekanisme menghambat pelepasan reninangiotensin yang dapat meningkatkan ekskresi natrium dan air, sehingga menyebabkan penurunan volume plasma, curah jantung dan tekanan perifer yang menyebabkan penurunan tekanan darah (Probosari et al., 2014). Dengan demikian, diyakini bahwa penurunan TDS maupun TDD terkait peran fenolik, BAL, asam amino, dan kalium yosukamera.

\section{Pengaruh Yosukamera terhadap BMI wanita SM}

Beberapa penelitian menunjukkan bahwa peningkatan BMI berkorelasi dengan tingginya lemak tubuh dan risiko munculnya penyakit di masa datang. Semakin tinggi BMI, semakin tinggi pula angka morbiditas dan mortalitas. Dua bulan setelah konsumsi Yosukamera, BMI menurun dari 28 menjadi $25 \mathrm{~kg} / \mathrm{m}^{2}(\mathrm{P}=0,039)$ dibandingkan placebo $(\mathrm{P}=0,64)$ maupun kontrol $(\mathrm{P}=0,36)$ (Gambar 4). Penurunan BMI juga terjadi dalam penelitian Chen et al. (2016), bahwa EGCG dengan dosis harian $(856,8 \mathrm{mg})$ secara signifikan menurunkan BMI dan lingkar pinggang pada 115 wanita dengan obesitas sentral. Akan tetapi, Bogdanski et al. (2012) melaporkan bahwa perubahan BMI tidak signifikan dalam penelitian double-blind terkontrol pada 56 obesitas pasien hipertensi menggunakan $379 \mathrm{mg} / \mathrm{hari}$ GCT. ECCG adalah Epigallocatechin gallate, yang juga dikenal dengan nama Epigallocatechin 3gallate, adalah senyawa ester dari epigallocatechin dan asam gallat dalam teh hijau, termasuk dalam kelompok senyawa fenolik.

Obesitas sentral, kriteria SM bukanlah obesitas secara umum, namun tingginya BMI $\left(28-31 \mathrm{~kg} / \mathrm{m}^{2}\right)$ membuktikan bahwa subjek juga mengalami obesitas. Makin tinggi BMI, permukaan jaringan adiposa makin luas, sehingga memacu terjadinya kekurangan $\mathrm{O} 2$ (hypoxia). Dalam kondisi seperti ini adiposa terpacu untuk melepaskan sitokin proinflamasi, kemokin, dan faktor angiogenik untuk meningkatkan aliran darah dan vaskularisasi. Dengan demikian tingginya BMI berkaitan erat dengan kondisi inflamasi. Hypoxia yang berlangsung lama (kronis) maka pelepasan sitokin proinflamasi terjadi secara kronis (Trayhurn dan Wood, 2005). 


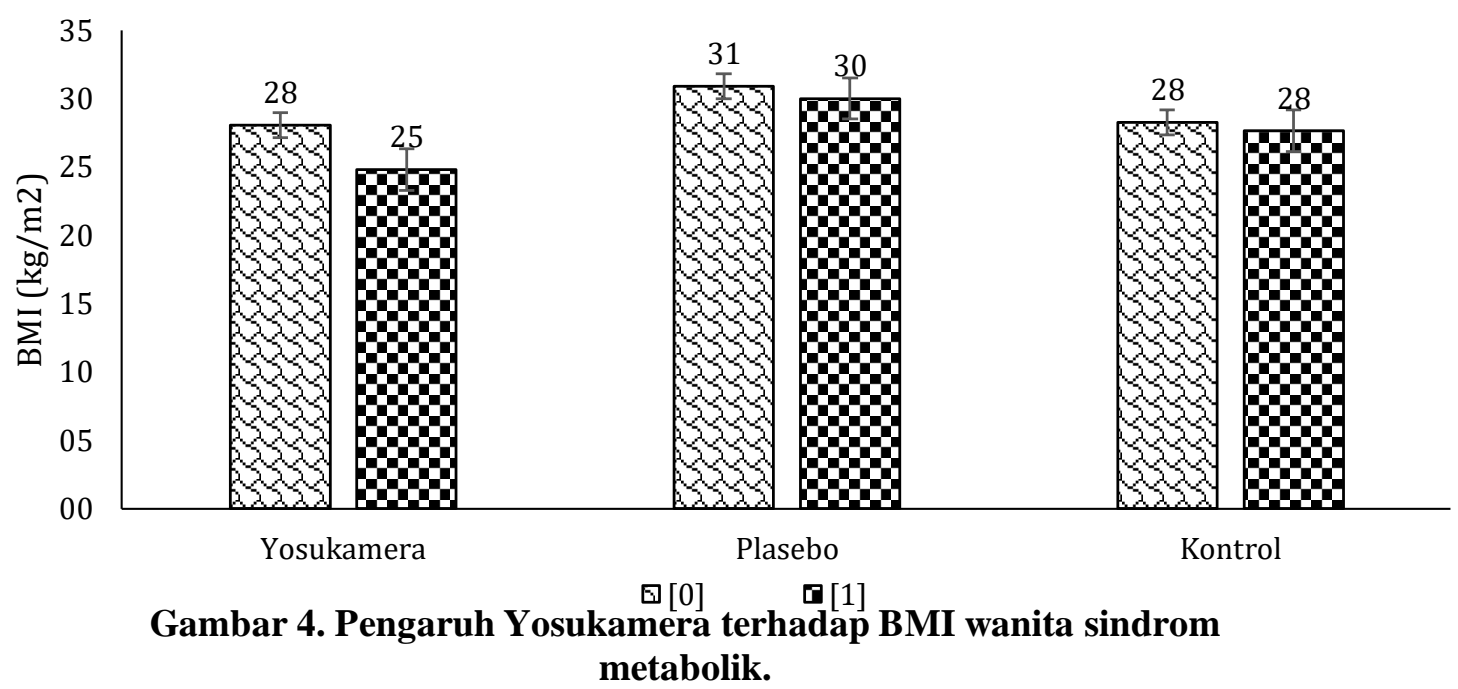

Salah satu teori menyatakan bahwa diet protein tinggi meningkatkan penurunan berat badan karena sifatnya termogenesis, berkaitan dengan peningkatan rasa kenyang dan penurunan asupan energi berikutnya (Halton dan $\mathrm{Hu}$, 2004). Hingga saat ini mekanisme protein dapat mempengaruhi rasa kenyang sukar dipahami. Namun demikian, Mellinkoff et al. (1956) menyebutkan bahwa rasa kenyang adalah interaksi psikologis yang rumit, terkait dengan mekanisme perilaku dan fisiologis. Teori yang dikembangkannya disebut hipotesis aminostatik, karena konsentrasi asam amino berkorelasi dengan berkurangnya nafsu makan, sehingga diyakini adanya pusat kenyang di otak. Dalam hipotesis tersebut pusatnya adalah kepekaan terhadap kadar asam amino serum hingga kadar tercapainya titik tertentu, sehingga rasa lapar berhenti. Hipotesisnya masuk akal karena itu kontrol asam amino menjadi pertimbangan utama pentingnya pertumbuhan dan pemeliharaan jaringan digabungkan dengan potensi toksisitas pada tingkat yang sangat tinggi.

Mekanisme lain yang memungkinkan adalah adanya hubungan antara rasa kenyang dan termogenesis yang disebabkan oleh pola makan. Dalam penelitian WesterterpPlantenga et al. (1999), perbedaan rasa kenyang selama periode 24 jam secara signifikan berkorelasi dengan perbedaan dalam 24 jam termogenesis yang diinduksi oleh waktu diet. Dengan demikian, penurunan BMI wanita sindrom metabolic ini juga terkait dengan asupan protein terlarut 
dalam Yosukamera.

Serat dalam yosukamera, dicernanya perlu waktu yang lama, dengan didukung sifatnya yang mudah menyerap air disekitarnya, menjadikan rasa kenyang lebih lama, sehingga membuat subjek tidak ingin makan dengan segera. Dengan demikian konsumsi makanan kaya serat secara memadai menjadikan berat badan menurun, demikian pula BMI nya. Karena itu Li dan Komarek (2017) merekomendasikan bahwa peningkatan konsumsi serat pangan menjadikan upaya yang aman dan praktis untuk mengurangi berat badan.

\section{KESIMPULAN}

Yosukamera dapat menurunkan lingkar perut sebesar $8,8 \%$, TDS $14,3 \%$, TDD 17,9\%, dan BMI 11,5\% melalui peran antioksidan fenolik, protein terlarut, maupun kandungan serat pangannya. Adanya perbaikan lingkar perut, tekanan darah, dan BMI tersebut dapat diyakini bahwa yogurt

\section{DAFTAR PUSTAKA}

Ansarullah A, Hardinsyah, Marliyati SA dan Astawan M. 2017, Efek Intervensi Minuman Tempe terhadap Tekanan Darah Penderita Hipertensi dan Hiperkolesterolemia. Jurnal Gizi dan Pangan. 12(2): 101-108.

Apostolidis E, Kwon YI, Ghaedian R dan Shetty K. 2007, Fermentation of Milk and Soymilk by Lactobacillus bulgaricus and Lactobacillus acidophilus Enhances Functionality for Potential Dietary Management of susu kecambah kacang merah sangat bermanfaat bagi kesehatan wanita sindrom metabolic, khususnya untuk mencegah perkembangannya kearah penyakit kardiovaskuler, stroke, maupun gagal ginjal.

Dalam penelitian ini penurunan BMI belum mencapai kriteria normal, namun melihat adanya signifikasi perubahan tersebut, maka sangat mungkin efeknya dapat lebih sempurna bila konsumsi dilanjutkan. Yosukamera dapat dikonsumsi sehari-hari agar diperoleh efek kesehatan yang maksimal.

\section{Ucapan Terimakasih}

Penulis mengucapkan terima kasih kepada Direktorat Jenderal Pengembangan dan Peningkatan Penelitian Kementerian Riset, Teknologi, dan Pendidikan Tinggi Indonesia, yang telah mendanai penelitian ini melalui skema Penelitian Berbasis Kompetensi Tahun Anggaran 2020.

Hyperglycemia and Hypertension, Food Biotechnology 21(3): 217-236.

Arianti I dan Husna CA. 2018. Hubungan lingkar pinggang dengan tekanan darah masyarakat di wilayah kerja Puskesmas Mon Geudong tahun 2015. https://ojs.unimal.ac.id/index.php/averrous/a rticle/viewFile/449/372

Bogdanski P, Suliburska J, Szulinska M, Stepien M, Pupek-Musialik D dan Jablecka A. 2012. Green tea extract reduces blood pressure, inflammatory biomarkers, and oxidative stress 
and improves parameters associated with insulin resistance in obese, hypertensive patients. Nutrition Research 32(6): 421427. doi:10.1016/j.nutres.2012.05.007

Buendia JR, Li Y, Hu FB Cabral HJ Bradlee ML, Quatromoni PA, Singer MR, Curhan GC dan Moore LL. 2018. Regular yogurt intake and risk of cardiovascular disease among hypertensive adults. American Journal of Hypertension 31(5): 557-565,

Cavallini DCU, Suzuki JY, Abdalla DSP, Vendramini RC, Pauly-Silveira ND, Roselino MN, Pinto RA, Rossi EA. 2011. Influence of a probiotic soy product on fecal microbiota and its association with cardiovascular risk factors in an animal model. Lipids in Health and Disease 10:126. doi: 10.1186/1476-511X-10-126

Chen Y, Huang L, Zhang H, Sun H and Zhou W. 2016. EGCG protective mitochondrial dysfunction after subarachnoid haemorrhage via inhibition p38 a pathway. Journal of Functional Foods 23: 115123. doi:10.1016/j.jff.2016.02.035

Cheng H. 2010. Volatile flavor compounds in yogurt: A Review. Critical Reviews in Food Science and Nutrition 50(10): 938-950.

Danuyanti IGAN, Kristinawati E dan Resnhaleksmana E. 2014, Hubungan kadar nitrit oksida (NO) dalam darah terhadap resiko kejadian diabetes mellitus tipe 2 dengan hipertensi di RSUP NTB, Jurnal Kesehatan Prima 8(1): 1207-1215.

Donkor ON, Henriksson A, Vasiljevic T and Shah NP. 2005. Probiotic strains as starter cultures improve Angiotensin-converting Enzyme inhibitory activity in soy yogurt. Journal of Food Science 70(8): 375-381.

Elkhtab E, El-Alfy M, Shenana M, Mohamed A and Yousef AE. 2017. New potentially antihypertensive peptides liberated in milk during fermentation with selected lactic acid bacteria and kombucha cultures. Journal of Dairy $\quad$ Science 100(12): 95089520. doi:10.3168/jds.2017-13150.

Faridi Z, Njike VY, Dutta S, Ali A and Katz DL. 2008. Acute dark chocolate and cocoa ingestion and endothelium function: a randomised controlled crossover trial. American Journal of Clinical Nutrition 88: 58-63.
Fernandez MA and Marette A. 2017. Potential health benefits of combining yogurt and fruits based on their probiotic and prebiotic properties. Advances in Nutrition, 8(1): 155S-164S.

Fujii H, Nishioka H, Wakame K, Magnuson BA and Roberts A. 2008. Acute, subchronic and genotoxicity studies conducted with Oligonol, an oligomerized polyphenol formulated from lychee and green tea extracts. Food and Chemical Toxicology 46(12): 35533562. doi:10.1016/j.fct.2008.06.005

Fujii H, Sun B, Nishioka H, Hirose A and Aruoma OI. 2007. Evaluation of the safety and toxicity of the oligomerized polyphenol oligonol. Food and Chemical Toxicology 45(3): 378387. doi:10.1016/j.fct.2006.08.026

Furuyashiki T, Nagayasu H, Aoki Y, Bessho H, Hashimoto T, Kanazawa $\mathrm{K}$ and Ashida $\mathrm{H}$. 2004. Tea catechin suppresses adipocyte differentiation accompanied by downregulation of PPAR $\gamma 2$ and $\mathrm{C} / \mathrm{EBP} \alpha$ in 3T3-L1 cells. Bioscience, Biotechnology, and Biochemistry 68(11): 23532359. doi:10.1271/bbb.68.2353

Grassi D, Lippi C, Necozione S, Desideri G and Ferri C. 2005. Short-term administration of dark chocolate is followed by a significant increase in insulin sensitivity and a decrease in blood pressure in healthy persons. American Journal of Clinical Nutrition 81: 611-614.

Haltona TL and Hu FB. 2004. The effects of high protein diets on thermogenesis, satiety and weight loss: A critical review. Journal of the American College of Nutrition 23(5): 373-385.

Hariri M, Salehi R, Feizi A, Mirlohi M, Kamali S, Ghiasvand R. 2015. The effect of probiotic soy milk and soy milk on anthropometric measures and blood pressure in patients with type II diabetes mellitus: A randomized double-blind clinical trial. ARYA Atheroscler. 11(Suppl 1): 74-80.

IDF concencus worldwide definition of the metabolic syndrome; 2005 [diakses pada 24 Oktober 2015]. Tersedia dari: http://www.idf.org

Ismail M, Hossain MF, Tanu AR and Shekhar HU. 2015. Effect of spirulina intervention on oxidative stress, antioxidant status, and lipid profile in chronic obstructive pulmonary disease patients. BioMed Research International $2015 . \quad$ Article ID 486120.7 p. https://doi.org/10.1155/2015/ 486120 
Kartini, Winarsi H, Dwiyanti H. 2018. Kandungan kalium dan antioksidan fenolik yogurt susu kecambah kacang merah yang termodifikasi kadar bal dan lama fermentasi untuk penderita hipertensi. Skripsi. Universitas Jenderal Soedirman, Purwokerto.

Kumalaningsih S, Maimunah HP, Raisyah. 2016. Substitusi sari kacang merah dengan susu sapi dalam pembuatan yogurt. Jurnal Teknologi dan Manajemen Agroindustri. 5(2): 54-60.

Khalesi S, Sun J, Buys $N$ and Jayasinghe R. 2014. Effect of Probiotics on Blood Pressure: A Systematic Review and Meta-Analysis of Randomized, Controlled Trials. Hypertension 64(4):

$897-$

903. doi:10.1161/hypertensionaha.114.03469

Lee Y-H and Pratley RE. 2007. Abdominal obesity and cardiovascular disease risk: the emerging role of the adipocyte. Journal of Cardiopulmonary Rehabilitation and Prevention. 27(1): 2-10. doi: 10.1097/01.HCR.0000265014.36587.dd

Li Y and Komarek AR. 2017. Dietary fibre basics: health, nutrition, analysis, and applications. Food Quality and Safety 1(1): 47-59.

Lu Y, Hajifathalian K, Ezzati M, Woodward M, Rimm EB and Danaei G. 2014. Metabolic mediators of the effects of body-mass index, overweight, and obesity on coronary heart disease and stroke: a pooled analysis of 97 prospective cohorts with 1,8 million participants. Lancet. 383(9921): 970-83.

Marti A, Marcos A and Martinez JA. 2001. Obesity and immune function relationships. Obesity Reviews 2(2): 131-140. doi:10.1046/j.1467789x.2001.00025.x

Martínez-González MA, Sayon-Orea C, Ruiz-Canela M, de la Fuente C, Gea A and BesRastrollo M. 2014. Yogurt consumption, weight change and risk of overweight/obesity: the SUN cohort study. Nutrition Metabolism and Cardiovascular Diseases 24: 1189-96.

Mellinkoff SM, Frankland M, Boyle D and Greipel M. 1956. Relationship between serum amino acid concentration and fluctuations in appetite. Journal of Applied Physiology 8: 535-588.

Nishihira J, Sato-Ueshima M, Kitadatec K, Wakamec $\mathrm{K}$ and Fujii $\mathrm{H}$. 2009. Amelioration of abdominal obesity by low-molecular-weight polyphenol (Oligonol) from lychee. Journal of Functional Foods 1: 341-348.

Nuryanti R, Rahayuningsih dan Murwani H. 2014. Pengaruh pemberian puding kacang merah (Vigna angularis) terhadap kadar glukosa darah puasa, tekanan darah dan lingkar pinggang obesitas hipertensi dan nonhipertensi pada remaja putri. http://eprints.undip.ac.id/45251/ [17 Juli 2020]

Oomah BD, Corbé A and Balasubramanian P. 2010. Antioxidant and anti-inflammatory activities of bean (Phaseolus vulgaris L.) hulls. Journal of Agricultural and Food Chemistry 58: 82258230 .

Pérez-Jiménez J, Hubert J, Hooper L, Cassidy A, Manach C, Williamson G and Scalbert A. 2010. Urinary metabolites as biomarkers of polyphenol intake in humans: a systematic review . The American Journal of Clinical Nutrition 92(4): 801-809. https://doi.org/10.3945/ajen.2010.29924

Pesta DH and Samuel VT. 2014. A high-protein diet for reducing body fat: mechanisms and possible caveats. Nutrition \& Metabolism 11(53): 1-8.

Probosari A. 2014, Pengaruh Pemberian Jus Mentimun (Cucumis sativus $l$ ) terhadap Penurunan Tekanan Darah pada Penderita Hipertensi Wanita Usia 40-60 Tahun, Journal of Nutition College, 3(4): 818-823.

Rampal S, Mahadeva S, Guallar E, Bulgiba A, Mohamed R, Rahmat R, Arif MT and Rampal L. 2012. Ethnic differences in the prevalence of metabolic syndrome: results from a multiethnic population-based survey in Malaysia. PLoS ONE 7(9): $\quad$ e46365. https://doi.org/10.1371/journal.pone.0046365.

Rangel-Huerta OD, Aguilera CM, Martin MV, Soto MJ, Rico MC, Vallejo $F$ and Mesa MD. 2015. Normal or high polyphenol concentration in orange juice affects antioxidant activity, blood pressure, and body weight in obese or overweight adults. The Journal of Nutrition 145(8): 1808-1816.

Rizzoli R. 2014. Dairy products, yogurts, and bone health. American Journal of Clinical Nutrition 99(5): 1256S-1262S.

Rodríguez MC, Medici M, Rodríguez AV, Mozzi F and Valdez GM. 2009. Prevention of chronic gastritis by fermented milks made with exopolysaccharide-producing Streptococcus 
thermophilus strains. Journal of Dairy Science 92(6):2423-34

Roowi S, Mullen W, Edwards CA and Crozier A. 2009. Yoghurt impacts on the excretion of phenolic acids derived from colonic breakdown of orange juice flavanones in humans. Molecular Nutrition \& Food Research 53: S6875.

Sandhu HS, Koley S, Sandhu KS. 2008. A study of correlation between lipid profile and waist to hip ratios in patients with diabetes mellitus. Anthropologist 10(3): 215-8.

Soewondo P, Purnamasari D, Oemardi M, Waspadji S, Soegondo S. 2010. Prevalence of metabolic syndrome using NCEP/ATP III criteria in Jakarta, Indonesia: the Jakarta primary non communicable disease risk factors surveilance 2006. Acta medica Indonesiana 42(4):199-203.

Sunarlim R dan Usmiati S. 2010. Kombinasi beberapa bakteri asam laktat terhadap karakteristik yogurt, Jurnal Penelitian. 326-335.

Taubert D, Roesen R, Lehmann C, Jung N and Schömig E. 2007. Effects of low habitual cocoa intake on blood pressure and bioactive nitric oxide. JAMA 298: 49-60

Thomas LH and Frank B. 2004. The effect of high protein diets on thermogenesis, satiety and weight loss. Journal of the American College of Nutrition 23(5): 373-385.

Tome D. 2004. Protein, amino acid and the control of food intake. British Journal of Nutrition 92(1): 27-30.

Trayhurn P and Wood IS. 2005. Adipokines: inflammation and the pleiotropic role of white adipose tissue. British Journal of Nutrition 92: 347-355.

Vasdev S and Gill V. 2008, The antihypertensive effect of arginine. International Angiology 17(1): 7-22. von Eyben FE, Mouritsen E, Holm J, Montvilas P, Dimcevski G, Suciu G, Helleberg I, Kristensen L and von Eyben R. 2003. Intraabdominal obesity and metabolic risk factors: a study of young adults. International Journal of Obesity 27: 941-949.

Westerterp KR, Wilson SAJ and Rolland V. 1999. Diet induced thermogenesis measured over $24 \mathrm{~h}$ in a respiration chamber: effect of diet composition. International Journal of Obesity 23: 287-292.

Westerterp-Plantenga MS, Rolland V, Wilson SAJ, Westerterp KR. 1999. Satiety related to $24 \mathrm{~h}$ diet-induced thermogenesis during high protein/carbohydrate vs high fat diets measured in a respiration chamber. European Journal of Clinical Nutrition 53: 495-502.

Winarsi H. 2013. Susu kecambah kedelai menurunkan marker IL-6 dan berat badan ibu menyusui. Prosiding Seminar Nasional PATPI 2013. Jember, 26-29 Agustus 2013

Winarsi H, Sasongko ND, Purwanto A. 2016. Germinated-soy milk in supressing inflammation and oxidative stress in blood plasma and breast milk of lactating mothers. International Food Research Journal 23(2): 646-652.

Winarsi H, Septiana AT, Kasnen SN. 2019. Germination increases more soluble protein, dietary fiber, and total phenolic contents of redkidney-bean-based yogurt, a functional drink for obese. Presented on The 3rd International Confer ence of Health Sciences 2019. Purwokerto, 17-18 July 2019.

Yamamoto M, Suzuki A and Hase T. 2008. Short-term effects of glucosyl hesperidin and hesperetin on blood pressure and vascular endothelial function in spontaneously hypertensive rats. Journal of Nutritional Science and Vitaminology 54(1): 9598. doi:10.3177/jnsv.54.95

Yang YY, Ma S, Wang XX and Zheng XL. 2017. Modification and application of dietary fiber in foods. Journal of Chemistry 1(1): 1-8. 